\title{
Effects of packaging materials and storage periods on seed quality and longevity dynamics of Pericopsis elata seeds
}

\author{
Paul K. Tandoh ${ }^{1,}$, Ben Banful ${ }^{1}$, Eli Gaveh ${ }^{1}$, James O. Amponsah ${ }^{2}$ \\ ${ }^{1}$ Kwame Nkrumah University of Science and Technology, 233 Kumasi, Ghana \\ ${ }^{2}$ Forestry Research Institute of Ghana, P. O. Box UP 63 KNUST, Kumasi, Ghana
}

Received: 1 July 2017

Accepted: 11 September 2017

Published online: 30 December 2017

\begin{abstract}
This study was carried out to determine the effects of packaging materials and storage periods on seed quality and longevity dynamics of an endangered tropical tree species, Pericopsis elata. The experimental period was December, 2015 to June, 2016. Seed collection was done at the Bobiri Forest Reserve. The seed storage experiment was set up using $3 \times 6$ factorial arrangements in Completely Randomized Design with three replications. Six packaging materials (jute, nylon, paper, ziplock bag, airtight bottle and no packaging) and three storage periods (no storage, three months storage and six months storage) were used. Germination percentage, seed vigour, 1000 seed weight, moisture content, carbohydrate, protein and oil contents were assessed before storage, three months and six months after storage. P. elata seeds with initial moisture content of $7.5 \%$ and packaged in airtight bottle and ziplock bags maintained their moisture contents even as storage periods increased. The initial amounts of seed carbohydrates $(1.9 \%)$, proteins $(37.4 \%)$ and oil $(31.3 \%)$ were maintained in the airtight packaging materials (bottle and ziplock bag) thereby improving seed storability. The seed viability equation predicted that $\mathrm{P}$. elata seeds could be stored for 243 years after six months of storage. Seed viability dropped to 164 days after the accelerated aging test was performed on the six-months old stored seeds. The study concluded that the seeds of this important endangered tree can be stored in airtight containers before the next planting season without any loss in seed quality.
\end{abstract}

Keywords: viability, endangered, vigour, airtight, peroxidation

\section{Introduction}

Pericopsis elata is from the Fabaceae family, known with the names afrormosia (DRC, Congo), assamela (Cameroon, Côte d'Ivoire) and kokrodua (Ghana). Commercially, the tree is known as African teak (with dark heartwood which is red in colour). Pericopsis elata (Meeuwen) is characteristic of the semi-deciduous forest (Swaine 1996) and is also an example of a long-lived light-demanding commercial species, together with Terminalia superba and Triplochiton scleroxylon (Abensperg-Traun 2009). Pericopsis elata is expensive due to the high quality of the wood, and its logging started over 50 years ago, mostly in Ghana and Côte d'Ivoire (Dickson et al. 005). In agroforestry systems, P. elata serves as an important tree used by cocoa farmers in Ghana to provide shade. P. elata seedlings used during field trials, survived despite low initial growth patterns (Anglaaere 2005).

Every year, about one million hectares in the tropics are planted with tree seedlings, but only a small percentage is indigenous due to the scanty scientific information on the quality and storage

\footnotetext{
${ }^{*}$ Corresponding author: P. K. Tandoh

e-mail: paulusnow@gmail.com
} 
potentials of their seeds (Bonner, 1992). Furthermore, seeds of many tropical forest species like P. elata quickly lose their viability and vigour before the next planting season due to improper seed handling activities including poor storage containers and conditions (Schmidt 2000). The tree is an endangered species (IUCN 2001) and special attention should be paid to the study of the tree's autecology and relevant information for its sustainability and conservation.

Forests are disappearing nearly one percent a year in sub-Saharan Africa at an alarming rate (FAO, 2003) and high quality tree seeds are needed to support both reforestation and the in and ex-situ conservation of forest genetic resources (Schmidt 2007). Several studies have indicated the effect of packaging materials on the quality of seeds in terms of germination and viability over a period of time. For instance Bortey et al. (2011) indicated that tomato seeds stored in a piece of cloth and tin containers resulted in low percentage germination and vigour compared to seeds stored in glass containers. However, it has been reported that the intensity of quality decreasing of stored seed under different storage techniques differ among plant species and within plant species (Al-Yahya 2001; Guberac et al. 2003). Using a sweet corn experiment, Camargo and Carvalho (2008) confirmed the advantages of employing hermetically sealed material to maintain quality of seed, under ambient environments. Moreover, Adebisi et al. (2008) included bottles as one of the best materials to store okra seeds. Seeds which are supposed to be planted in the subsequent season need to be dried and stored in moisture barrier materials to control loss of viability and vigour (Justice and Bass 1979). Thus, the choice of material used in storing seed is crucial in ensuring that the quality of seed is maintained during storage. Moreover, since the effect of these storage materials on the quality of seeds of different crops may vary, it is important to investigate and establish the most suitable packaging material for long term conservation of forest genetic resources. This would provide the gene bank managers information on how to maintain the integrity of the seed during storage. It is against this background that this study was conducted to determine the effects of packaging materials and storage periods on seed quality (physiological and biochemical) and to predict the longevity of Pericopsis elata seeds

\section{Materials and methods}

\subsection{Location of seed collection and seed storage experiment}

Bobri Forest Reserve was the selected location for the seed collection activities which took place in December, 2015. This Forest Reserve is in the south-east sub-type of moist semi-deciduous (MSSE) forest in Ghana, making an area of about 5,445 ha (Alder 1993). It is located 35km southeast of the regional capital and $2.5 \mathrm{~km}$ off the main Kumasi-Accra road at the village of Kubease (Fig.1). It lies on latitude $06^{0} 40^{\prime} \mathrm{N}$ to $6^{0} 44^{\prime} \mathrm{N}$ and longitude $01^{0} 15^{\prime} \mathrm{W}$ to $01^{0} 22^{\prime} \mathrm{W}$. The reserve serves as a research site for the Council for Scientific and Industrial Research-Forestry Research Institute of Ghana (CSIRFORIG). It is a biodiversity conservation site home to many plants and animal species. Deciduous and evergreen species are represented in about equal proportion often with several canopy layers (Hall and Swaine 1981). The climate has a peak rainfall period in June-July, September-October and a marked dry season in November through March. The maximum and minimum temperatures are $36^{\circ} \mathrm{C}$ and $24.4^{0} \mathrm{C}$.

The seed storage and other laboratory experiments were conducted at the Department of Horticulture, KNUST.

\subsection{Experimental design}

A $3 \times 6$ factorial completely randomized design in three replications was used for this experiment. The factors considered were: three storage periods (no storage, three months storage and six months) and six packaging materials [jute $(0.9 \mathrm{~mm}$ thickness $)$, nylon $(0.5 \mathrm{~mm})$, paper $(0.2 \mathrm{~mm})$, 
P. K. Tandoh et al.

ziplock bag $(0.3 \mathrm{~mm})$, airtight bottle and no packaging]. The seeds were desiccated to same moisture content of $3.5 \%$ using $0.5 \mathrm{~kg}$ of zeolite beads

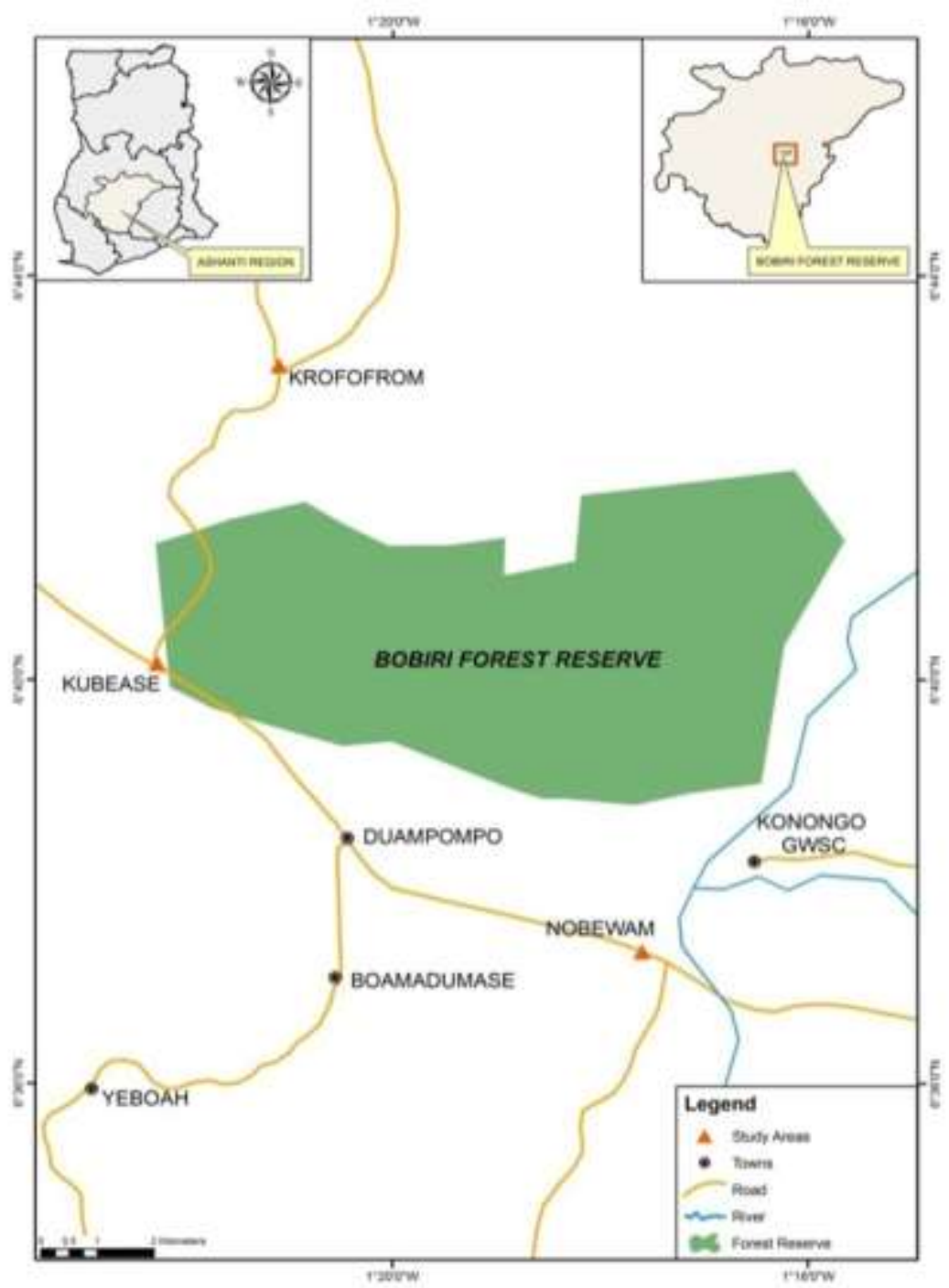

Source: of 5 Remote Sensing and Cartography Unin, Departivent of Geograpty and Regioeal Planning

Fig. 1 The map of Bobiri Forest Reserve.

\subsection{Parameters studied}

These seed quality parameters (1000 seed weight, germination percentage and seed vigour) were determined using the rules set out in ISTA (2007). The chemical seed composition (oil, moisture content, protein and carbohydrate were determine using the rules set out in AOAC (2007).

\subsection{Vigour index determination}

The vigour index formula proposed by Abdul-Baki and Alderson (1973) was used.

Vigour Index $=($ Shoot length + Root length $) X$ Germination Percentage

\subsection{Measurement of temperature and relative humidity of storage environment}

The ambient storage room temperature and relative humidity readings were taken at specified times of 9:00 am, 12:00 pm and 6.00 pm to minimize potential variations and microclimate fluctuations. 
P. K. Tandoh et al.

Acurite manufactured indoor digital humidity and temperature monitor (00325) was used in taking the readings which is shown in Tab. 3 .

\subsection{Accelerated ageing test}

Accelerated Ageing test was carried out at the end of the sixth month storage using the description proposed by Jianhua and McDonald (1996)

\subsection{Using the seed viability equation to predict longevity of stored seeds}

At the end of the 6 months storage seeds were aged and their longevity was determined using the seed viability equation (Eq. 1) proposed by Ellis and Roberts (1980).

$$
v=K_{\mathrm{i}}-p / 10^{K_{\mathrm{E}}-C_{\mathrm{W}} \log m-C_{\mathrm{H}^{t}-C_{Q^{t}}}}
$$

Eq. 1

(Ellis and Roberts, 1980)

$\mathbf{v}=$ final viability (expressed as \%, NEDs or probits) after $\mathrm{p}$ days storage.

$\mathbf{P}=$ storage time (days)

$\mathbf{m}=\%$ moisture content (fresh weight basis)

$\mathbf{t}=$ temperature $\left({ }^{\circ} \mathrm{C}\right)$

$\mathbf{K}_{\mathbf{i}}=$ initial viability of the seed lot at $\mathrm{p}=0$ days (seed lot constant)

$\mathbf{C}_{\mathbf{H}}$ and $\mathbf{C}_{\mathbf{Q}}=$ species-specific temperature constants

$\mathbf{K}_{\mathbf{E}}$ and $\mathbf{C}_{\mathbf{W}}=$ species-specific moisture content constants.

$\mathrm{C}_{\mathrm{H}}$ and $\mathrm{C}_{\mathrm{Q}}$ are species-specific temperature constants. The effect of temperature on seed longevity is similar for all species, at least between $-30^{\circ} \mathrm{C}$ and $+90^{\circ} \mathrm{C}$, and if individual constants are unknown the "universal" $\mathrm{C}_{\mathrm{H}}$, and $\mathrm{C}_{\mathrm{Q}}$ constants of 0.0329 and 0.000478 may be used. Storage temperature after six months storage $=28.78^{\circ} \mathrm{C}$ and $47^{\circ} \mathrm{C}$ during the aging period.

\subsection{Data analysis}

Data collected from the experiment were subjected to analysis of variance using Statistical Software Version 9.0. Tukey's HSD (Honest Significant Difference) was used for mean separation at probability level set at $\mathrm{p}=0.01$.

\section{Results}

\subsection{Initial seed quality characteristics}

The initial seed moisture, vigour, vigour index of 1000 seed weight and germination percentage were 7.5\%, $23 \mu \mathrm{S}^{\mathrm{cm}-1} \mathrm{~g}^{-1}, 2689.7,254.7 \mathrm{~g}$ and $96.3 \%$ respectively (Tab. 1). The initial seed oil, protein and carbohydrate were $31 \%, 37.4 \%$ and $1.9 \%$ respectively (Tab. 2)

Tab.1 Initial seed quality characteristics of $P$. elata seeds.

\begin{tabular}{cccccc}
\hline Species & $\begin{array}{c}\text { Moisture } \\
\text { Content }(\%)\end{array}$ & $\begin{array}{c}\text { Vigour } \\
\left(\mu \mathrm{S} \mathrm{cm}^{-1} \mathrm{~g}^{-1}\right)\end{array}$ & $\begin{array}{c}\text { Vigour } \\
\text { Index }\end{array}$ & $\begin{array}{c}1000 \text { seed weight } \\
(\mathrm{g})\end{array}$ & $\begin{array}{c}\text { Germination } \\
(\%)\end{array}$ \\
\hline P. elata & 7.5 & 23.0 & 2689.7 & 254.7 & 96.3 \\
\hline
\end{tabular}


P. K. Tandoh et al.

Tab.2: The initial proximate composition of $P$. elataseeds.

\begin{tabular}{lccc}
\hline Species & Oil & Protein & Carbohydrate \\
& $\%$ & $\%$ & $\%$ \\
\hline P. elata & 31.3 & 37.4 & 1.9 \\
\hline
\end{tabular}

\subsection{Ambient conditions of storage}

Relative humidity range between $63.2 \%$ and $77.82 \%$ whereas the temperature was between $27.9^{\circ} \mathrm{C}$ and $28.2^{\circ} \mathrm{C}$. The minimum relative humidity was recorded in January, 2016 and the maximum in June, 2016. The minimum temperature was recorded in January, 2016 and the maximum in March, 2016 (Tab.3).

Tab.3 The relative humidity and temperature for the storage environment.

\begin{tabular}{lcc}
\hline Month & Relative Humidity & Temperature \\
\hline January & 63.2 & 28.2 \\
February & 64.5 & 29.1 \\
March & 75.45 & 29.45 \\
April & 72.3 & 29.79 \\
May & 76.46 & 28.21 \\
June & 77.82 & 27.9 \\
\hline
\end{tabular}

\subsection{Effects of packaging materials and storage periods on carbohydrate content}

Significant packaging material and storage period interactions were observed in the percent carbohydrate of $P$. elata seeds (Tab. 4). Seeds in airtight bottle which were not stored produced significantly highest percent carbohydrate, although not different from seeds stored in airtight bottles and ziplock for three and six months of storage periods. The jute packaged seeds stored for six months showed the least carbohydrate content yet not different from those stored in nylon bags, paper bags and the unpackaged.

Tab.4 Effect of packaging materials and storage periods on carbohydrate of P. elata.

\begin{tabular}{lcccc}
\hline Packaging Materials & \multicolumn{4}{c}{ Storage Periods } \\
& 0 Month & 3 months & 6 Months & Mean \\
\hline Jute & 1.21 & 0.70 & 0.3 & 0.74 \\
Nylon & 1.22 & 0.80 & 0.4 & 0.81 \\
Paper & 1.23 & 0.75 & 0.45 & 0.81 \\
Ziplock & 1.23 & 1.20 & 1.00 & 1.17 \\
Airtight bottle & 1.25 & 1.24 & 1.10 & 1.20 \\
No Packaging & 1.20 & 0.60 & 0.35 & 0.72 \\
Means & 1.22 & 0.90 & 0.60 & - \\
\hline Tukeys & HSD & Pack. Material=0.3 Storage Periods $=0.2$ Pack Mat. x Storage periods $=0.7$ \\
$(0.01):$ & \multicolumn{5}{l}{}
\end{tabular}




\subsection{Effects of packaging materials and storage periods on $P$. elata seed oil}

Significant packaging material and storage period interactions were observed in the percent oil of $P$. elata seeds (Tab.5). Seeds in any of the packaging materials but not stored showed significantly the highest percent oil content. However, the unpackaged seeds stored for six months had the least oil content.

Tab.5 Effects of storage periods and packaging materials on oil content of P. elata.

\begin{tabular}{lcccc}
\hline \multirow{2}{*}{ Packaging materials } & \multicolumn{4}{c}{ Storage periods } \\
\hline Jute & 0 Month & 3 months & 6 Months & Mean \\
Nylon & 31.08 & 26.83 & 24.83 & 27.58 \\
Paper & 31.23 & 27.83 & 25.33 & 28.13 \\
Ziplock & 31.33 & 28.33 & 25.88 & 28.50 \\
Airtight bottle & 30.83 & 29.83 & 28.33 & 29.66 \\
No Packaging & 31.27 & 30.63 & 28.83 & 30.24 \\
Means & 31.03 & 25.83 & 23.67 & 26.84 \\
& 31.13 & 28.22 & 26.14 \\
\hline HSD (1\%): Pack. Material= 1.2 Storage Periods=0.7 Pack Mat. x Storage periods=2.6
\end{tabular}

\subsection{Effects of packaging materials and storage periods on protein content}

There were significant differences between the storage periods for the protein content of $P$. elata seeds (Tab.6). Significantly highest protein was produced by seeds which were not stored $(37.81 \%)$, while the least was produced by seeds stored for 6 months $(36.36 \%)$.

Tab.6 Effect of storage periods on the protein content of $P$. elata seeds.

\begin{tabular}{ll}
\hline Storage Periods & Protein $(\%)$ \\
\hline No storage & 37.81 \\
3 Months storage & 37.32 \\
6 months storage & 36.36 \\
\hline HSD (1\%) & 0.8 \\
\hline
\end{tabular}

\subsection{Effects of packaging materials and storage periods on germination percentage}

Seeds in airtight bottle without storage recorded the highest germination (96.33\%) although not significantly different from seeds stored in airtight bottle (93.33\%) and ziplock bags (92.40\%) for six months. The least was recorded by unpackaged seeds stored for six months (69.67\%) yet similar to seeds stored in jute bag (71.33\%), nylon $(72.33 \%)$ and paper bags $(73.30 \%)$ for the same period (Tab. 7). 
Environment, Earth and Ecology Vol. 1 No. 2 (2017), 27 - 38

DOI: $10.24051 / \mathrm{eee} / 76919$

P. K. Tandoh et al.

Tab.7 Effect of packaging materials and storage periods on the germination percentage of $P$. elata seeds.

\begin{tabular}{lcccc}
\hline \multirow{2}{*}{ Packaging materials } & \multicolumn{4}{c}{ Storage periods } \\
& 0 Month & 3 months & 6 Months & Mean \\
\hline Jute & 93.31 & 81.33 & 71.33 & 82.54 \\
Nylon & 93.33 & 83.32 & 72.32 & 82.67 \\
Paper & 94.32 & 84.33 & 73.30 & 84.23 \\
Ziplock & 95.10 & 93.40 & 92.40 & 91.33 \\
Nirtight bottle & 96.33 & 95.43 & 93.33 & 92.40 \\
Means & 92.33 & 80.31 & 69.67 & 80.44 \\
\hline HSD (1\%): Pack. Material=2.5 & Storage Periods= 1.5 Pack Mat. x Storage periods= 5.3 \\
\hline
\end{tabular}

\subsection{Effects of packaging materials and storage periods on moisture content}

Seeds in airtight bottle without storage had significantly the lowest moisture content (3.33\%), yet similar to all the other treatment combinations except seeds in jute package stored for six months and unpackaged seeds stored for three and six months. Unpackaged seeds stored for six months had the highest moisture content which was similar to the seeds in jute package stored for six months (Tab. 8).

Tab.8 Effect of packaging materials and storage periods on the moisture content of $P$. elata seeds.

\begin{tabular}{lcccc}
\hline \multirow{2}{*}{ Packaging materials } & 0 month & 3 months & 6 Months & Mean \\
\hline Jute & 3.53 & 5.03 & 6.03 & 4.94 \\
Nylon & 3.63 & 4.63 & 5.33 & 4.84 \\
Paper & 3.73 & 3.83 & 5.8 & 4.77 \\
Ziplock & 3.38 & 3.34 & 3.45 & 3.35 \\
Airtight bottle & 3.33 & 3.33 & 3.38 & 3.32 \\
No Packaging & 3.83 & 6.33 & 7.17 & 5.78 \\
Means & 3.52 & 4.42 & 5.03 & \\
\hline HSD $(0.01):$ Pack & Material $=1.2$ & Storage Periods=0.7 Pack Mat x Storage periods $=2.6$
\end{tabular}

\subsection{Effects of packaging materials and storage periods on vigour}

Unpackaged seeds stored for six months recorded significantly the highest vigour $\left(34.90 \mu \mathrm{Scm}^{-}\right.$ $\left.{ }^{1 \mathrm{~g}-1}\right)$, which was not different from seeds packaged in jute bags $\left(34.80 \mu \mathrm{Scm}^{-1 \mathrm{~g}-1}\right)$, nylon $\left(34.85 \mu \mathrm{Scm}^{-}\right.$ $\left.{ }^{1 \mathrm{~g}-1}\right)$ and paper bags $\left(34.10 \mu \mathrm{Scm}^{-1 \mathrm{~g}-1}\right)$. The least vigour was produced by seeds in airtight bottle without storage $(22.85 \mu \mathrm{Scm}-1 \mathrm{~g}-1)$ but similar to seeds packaged in airtight bottle $(23.85 \mu \mathrm{Scm}-1 \mathrm{~g}-1)$ and ziplock bags (23.85 $\mu \mathrm{Scm}-1 \mathrm{~g}-1)$ and stored for six months(Tab. 9). 
P. K. Tandoh et al.

Tab.9 Effect of packaging materials and storage periods on the vigour of $P$. elata seeds.

\begin{tabular}{lcccc}
\hline & \multicolumn{4}{c}{ Storage periods } \\
Packaging materials & 0 Month & 3 months & 6 Months & Mean \\
\hline Jute & 24.85 & 28.35 & 34.80 & 28.69 \\
Nylon & 24.45 & 27.85 & 34.85 & 27.72 \\
Paper & 24.65 & 26.81 & 34.10 & 27.12 \\
Ziplock & 22.90 & 22.94 & 23.85 & 25.18 \\
Airtight bottle & 22.85 & 22.95 & 23.85 & 24.72 \\
No Packaging & 24.84 & 29.83 & 34.90 & 28.78 \\
Means & 24.17 & 27.367 & 30.10 & \\
\hline
\end{tabular}

HSD (1\%): Pack. Material=0.5 Storage Periods= 0.3 Pack Mat. $\mathrm{x}$ Storage periods= 1.1

\subsection{Effects of packaging materials and storage periods on vigour index}

Seeds in airtight bottle with no storage recorded significantly highest vigour index (2668.30) which was similar to seeds stored for six months in airtight bottle (2665.34) and ziplock bags (2664.35). The least vigour index was recorded by seeds unpackaged and stored for six months which was not different from those stored in jute, nylon and paper bags and stored for the same period (Tab. 10).

Tab.10 Effect of packaging materials and storage periods on the vigour index of P. elata seeds.

\begin{tabular}{lcccc}
\hline \multirow{2}{*}{ Packaging materials } & \multicolumn{4}{c}{ Storage periods } \\
& 0 months & 3 months & 6 Months & Mean \\
\hline Jute & 2604.41 & 2106.20 & 1422.32 & 2042.72 \\
Nylon & 2576.20 & 2158.10 & 1421.43 & 2041.30 \\
Paper & 2632.14 & 2184.30 & 1420.53 & 2041.31 \\
Ziplock & 2665.30 & 2662.32 & 2664.35 & 2180.70 \\
Airtight bottle & 2668.35 & 2663.43 & 2665.34 & 2181.73 \\
No Packaging & 2604.40 & 2080.55 & 1419.72 & 2042.85 \\
Means & 2627.72 & 2067.12 & 1473.62 & \\
\hline
\end{tabular}

HSD (1\%): Pack. Material=2.5 Storage Periods= 1.5 Pack Mat. $\mathrm{x}$ Storage periods=5.3

\subsection{Effects of packaging materials and storage periods on 1000 seed weight}

Seeds in airtight bottle without storage recorded the highest thousand seed weight which was not different from seeds stored in airtight bottles and ziplock bags for six months and 3 months. The unpackaged seeds stored for six months and three months recorded significantly the lowest thousand seed weight which was similar to seeds stored for six months and 3 months in jute bags, nylon bags and paper bags (Tab. 11). 
Tab.11 Effects of packaging materials and storage periods on the thousand seed weight of $P$. elata seeds.

\begin{tabular}{lrrrc}
\hline & \multicolumn{4}{c}{ Storage periods } \\
Packaging materials & 0 months & 3 months & 6 Months & Mean \\
\hline Jute & 249.33 & 232.33 & 235.31 & 238.67 \\
Nylon & 248.31 & 233.33 & 237.33 & 237.67 \\
Paper & 249.33 & 237.33 & 239.32 & 238.22 \\
Ziplock & 250.30 & 248.33 & 247.33 & 248.34 \\
Airtight bottle & 251.33 & 249.33 & 243.13 & 248.62 \\
No Packaging & 247.32 & 235.33 & 237.10 & 239.22 \\
Means & 259.33 & 254.33 & 247.61 & \\
\hline
\end{tabular}

HSD (1\%): Pack. Material=5.7 Storage Periods=4.1 Pack Mat. x Storage periods=6.1

\subsection{Estimate of seed longevity after 6 months of storage and accelerated aging of $P$. elata seeds}

P. elata seeds stored in airtight bottle after six months had a predicted longevity of 243 years and those not packaged had 5 years. After the six months when the seeds were aged, the longevity greatly dropped to 164 days for the airtight bottle and 20 days for the no packaging (Tab.12).

Tab.12 Estimate of seed longevity after 6 months storage and accelerated aging of P. elata seeds.

\begin{tabular}{lcc}
\hline $\begin{array}{l}\text { Packaging } \\
\text { Materials }\end{array}$ & $\begin{array}{c}\text { After } 6 \text { months of storageAfter accelerated aging } \\
\text { Longevity (years) }\end{array}$ & $\begin{array}{c}\text { Longevity (Days) } \\
\text { Jute }\end{array}$ \\
Nylon & 11 & 31 \\
Paper & 21 & 49 \\
Ziplock & 38 & 64 \\
Airthight bottle & 200 & 155 \\
No packaging & 243 & 164 \\
\hline
\end{tabular}

\section{Discussion}

Seeds stored in airtight and ziplock bags for three and six months periods had the highest seed quality but those which were not packaged but stored for 3 months and six months had reduced seed quality. The other porous materials like jute, nylon and paper also lost their quality considerably in storage. Additionally, an increase in storage periods under relatively high temperature and humidity also caused a reduction in vigour and viability of the stored $P$. elata seeds. These observations could be due to the rapid exchange of gases between the seeds and their ambient environment under high relative humidity for the storage experiment, resulting in reabsorption of moisture by the seeds due to their hygroscopic nature thereby enhancing metabolic activities and oxidation processes. These metabolic activities and oxidation processes eventually depleted the essential food reserves in the seed leading to gradual loss of vigour and viability. According to Tonin and Perez (2006), the type of packaging at the time of seed storage becomes extremely relevant on the quality indicators, when the packaging can 
minimize the rate of seed spoilage, and continue to regulate the initial water content of seeds in storage, preventing the speed at which seeds respire. Furthermore, in the process of seed deterioration, the increase on peroxidation of lipids results in damages to the cell membrane, and consequent generation of toxic by-products (Schwember and Bradford 2010). There was therefore the need to use moisture proof containers like the airtight bottle and the ziplock material which served as barrier against gaseous exchange and maintaining the quality of the seeds within the period of storage. The results of the current study also supports the findings of Schmidt (2000) mentioned that seeds of tropical trees, stored into a low oxygen levels, reduce the rate at which their seeds deteriorate and age. Sastry et al. (2007) also reported that seeds with low moisture content reduced respiration and deterioration and thereby enhanced the quality of stored seeds. Seeds stored in airtight bottle and ziplock bags for three months and six months periods had the highest carbohydrate, oil and protein contents but those which were not packaged but stored for three months and six months had reduced amounts. As the storage periods increased, the loss of carbohydrates, proteins and oils also reduced rapidly. Such observations could be attributed to the hydrolysis of available carbohydrates into sugars, peroxidation of seed oil and possible denaturation of storage proteins as storage duration increased. According to Bemal-Lugo and Leopold (1992), carbohydrate hydrolysis into sucrose reduced vigour and germinability of stored seeds over time. Nagel and Börner (2010) reported that lipid peroxidation could be non-enzymatic (auto peroxidation) or enzymatic (lipooxygenase) and both mechanisms lead to aging in seed. Murthy and Sun (2000) also indicated that lipid peroxidation could give rise to secondary products that could denature proteins and DNA in a non-enzymatic manner by means of the Maillard and Amadori reactions. Furthermore, Mutters (2003) reported that chemical constituents greatly change in storage especially within 3-4 months at very high temperatures. Results of this study agrees with previous findings that the consequence of peroxidation of polyunsaturated fatty acids of seed membranes was the destabilization of the membranes, which lead to uncontrolled leakage of solutes (Priestley et al., 1980). The results of this study showed that seed vigour significantly decreased after increasing the storage periods which eventually caused seed deterioration. $P$. elata can be stored for longer periods in airtight containers and that the accelerated aging conditions fastened the deterioration of the seeds, hence reducing their viability drastically. This suggests that under harsh conditions when seeds are aged, seed moisture increases under high temperature and relative humidity which promotes protein degradation, sugar hydrolysis, rise in metabolic and oxidation reactions. Murthy et al. (2002) opined that temperature and moisture content are the most important factors affecting the rate of seed deterioration and that a wide range of seed water contents and storage temperatures was used to determine the relationship between advances in seed aging and several possible primary biochemical deterioration processes, including lipid peroxidation and sugar hydrolysis.

\section{Conclusion}

Results obtained from this study has shown that airtight bottle and ziplock bag used for storage of $P$. elata seeds improved viability of seeds stored for three and six months as compared to jute, paper, nylon and no packaging materials. Airtight bottle and ziplock bag which are non-porous materials maintained seed moisture, vigour, vgour index, protein, carbohydrate and oil contents. Seed deterioration was minimized in theses packaging materials as compared to the others (jute, nylon, paper and the unpackaged seeds) however temperature and relative humidity were high and fluctuated under ambient storage conditions which ultimately contributed to reducing seed quality and longevity. After the sixth month storage, longevity (years) of P. elata was 243 years when stored in airtight bottles. When seeds were aged artificially, their longevity hugely reduced to 164 days. 


\section{Acknowledgement}

We are profoundly grateful to the International Tropical Timber Organization (ITTO) in Japan for funding the field work under the Freezailah Fellowship Programme.

\section{References}

Abdul-Baki AA, Alderson JD (1973) Vigor determinations in soybean seed multiple criteria. Crop Science journal vol 13; 630-633pp.

Alder D (1993) Growth and Yield Research in Bobri Forest Reserve. ODA/Forestry Research Institute of Ghana. Unpublished Consultancy report, $71 \mathrm{pp}$. maintenance of mature seeds: studies with the Cape Verde Islands ecotype, the dormant model of Arabidopsis thaliana. Planta 219:479-488

Al-Yahya SA (2001) Effect of Storage Conditions on Germination in Wheat. Journal of Agronomy and Crop Science, 186, 273-279. http://dx.doi.org/10.1046/j.1439-037x.2001.00402.x

Anglaaere, LCN (2005). Improving the sustainability of cocoa farms in Ghana through utilization of native forest trees in agroforestry systems. PhD thesis: University of Wales, Bangor (UK).

AOAC International (2007) Official methods of analysis, 18th edn., 2005; Current through revision 2, 2007 (Online). AOAC International, Gaithersburg, MD.

Adebisi MA, Daniel IO, Ajala MO (2008) Storage life of soybean (Glycine max L. Merril) seeds after seed dressing. J. Trop. Agric. 42(1-2):3-7.

Bernal-Lugo I, Leopold AC (1998) The dynamics of seed mortality. J. Exp. Bot. 49: 1455-1461.

Bonner FT (1992)Seed technology. A challenge for tropical forestry.Tree Planters Notes- USDA Forest Service. pp. 142-145.

Bortey HM, Olympio NS, Banful B (2011) Quality of farmer-saved tomato (Lycopersicon esculentum Mills.) seeds and its effect on fruit yield in Ghana. Ghana Journal of Horticulture, 9, 25-33.

Camargo R, Carvalho, MLM (2008) Armazenamento a vácuo de semente de milhodoce. Revista Brasileira de Sementes, v.30, n.1, p.131-139,. http://dx.doi.org/10.1590/S010131222008000100017.

Dickson B, Mathew P, Mickleburgh S, Oldfield S, Pouakouyou D, Suter J (2005). An assessment of the conservation status, management and regulation of the trade in Pericopsis elata. Cambridge, UK: Fauna \& Flora International.

Ellis RH, Roberts EH (1980) Improved equations for the prediction of seed longevity. Annals of Botany, 45(1), 13-30.

FAO (2003)State of the world's forest, Rome, Italy.

ISTA (2007) International Rules for Seed Testing. International Seed Testing Association, Bassersdorf, Switzerland.

IUCN (2001) IUCN Red List of threatened species. Gland, Switzerland: IUCN Species Survival Commission.

Guberac V, Maric S, Lalic A, Drezner G, Zdunic Z (2003)Hermetically Sealed Storage of Cereal Seeds and its Influence on Vigour and Germination. Journal of Agronomy and Crop Science, 189, 54-56. http://dx.doi.org/10.1046/j.1439-037X.2003.00596.x

Hall JB, Swaine MD (1981) Distribution and ecology of vascular plants in a tropical rainforest. Forest Vegetation in Ghana. The Hague: W. Junk.

Jianhua Z, Mcdonald MB (1997) The saturated salt accelerated aging test for small-seeded crops. Seed Science and Technology, 25(1), 123-131.

Justice OH, Bass HN (1979) International rules for seed testing Seed Sci. and Technol., vol 21, pp 25 46.

Murthy UMN, Kumar PP, Sun WQ, (2003) Mechanisms of seed ageing under different storage conditions for Vigna radiata (L.) Wilczek: lipid peroxidation, sugar hydrolysis, maillard reactions and their relationship to glass transition. J. Exp. Bot. 54:1057-1067.

Murthy UMN, Sun WQ (2000) Protein modification by Amadori and Maillard reactions during seed storage: roles of sugar hydrolysis and lipid peroxidation. J. Exp. Bot. 51:1221-1228.

Mutters RG (2003) Concept of Rice Quality. http://www.agronomy.ucdavis.edu/uccerice /Quality/concepts. 
P. K. Tandoh et al.

Nagel M, Börner A (2010) The longevity of crop seeds stored under ambient conditions. Seed Science Research, 20(1), p.1.

Priestley DA, McBride MB, Leopold C (1980) Tocopherol and organic free radical levels in soybean seeds during natural and accelerated aging. Plant Physiology, 66(4),715-719.

Sastry DVSSR, Upadhyaya HD, Gowda, CLL (2007) Survival of groundnut seeds under different storage conditions. Journal of SAT Agricultural Research, 5, p.3pp.

Schmidt L ( 2000) Guide to handling of tropical and subtropical forest seed (pp. 292-293). Denmark: Danida Forest Seed Centre.

Schmidt LH (2007) Tropical forest seed. Springer Science and Business Media, 2007

Schwember AR, Bradford K (2010) Quantitative trait loci associated with longevity of lettuce seeds under conventional and controlled deterioration storage conditions. J. Exp. Bot. 61(15):4423-4436 Seed Sci. Res. 20:1-12.

Swaine MD (1996) Rainfall and soil fertility as factors limiting forest species distributions in Ghana. Journal of Ecology, pp.419-428.

Tonin GA, Perez SCJGD (2006) Qualidade fisiológicade sementes de Ocotea porosa (Nees et Martius ex. Nees) após diferentes condições de armazenamento e semeadura. Revista Brasileira de sementes. 